\title{
Springtime changes in snow chemistry lead to new insights into mercury methylation in the Arctic
}

\author{
Catherine Larose ${ }^{\mathbf{a}, \mathbf{b}, \mathbf{c}}$, Aurélien Dommergue ${ }^{\mathbf{a},{ }^{*},}$, Martine De Angelis ${ }^{\mathbf{a}}$, Daniel Cossa ${ }^{\mathbf{d}}$, Bernard Averty ${ }^{\mathbf{e}}$ \\ Nicolas Marusczak ${ }^{a}$, Nicolas Soumis ${ }^{a}$, Dominique Schneider ${ }^{b}, \mathrm{c}$ and Christophe Ferrari ${ }^{\mathrm{a}}$
}

\author{
a Université Joseph Fourier - Grenoble 1/CNRS, LGGE, 54 rue Molière BP 56, F-38402 Saint Martin \\ d'Hères, France \\ b Laboratoire Adaptation et Pathogénie des Microorganismes, Université Joseph Fourier Grenoble 1, \\ BP 170, F-38042 Grenoble Cedex 9, France \\ ${ }^{\mathrm{c}}$ CNRS UMR 5163, France \\ d Ifremer, Centre de Méditerranée, BP 330, F-83507 La Seyne sur mer, France \\ e Ifremer, Centre de Nantes, BP 21105, F-44311 Nantes Cedex, France
}

\author{
*: Corresponding author: Aurélien Dommergue, Tel.: +33 04768242 11; fax: +33 04768242 01, email \\ address: dommergue@lgge.obs.ujf-grenoble.fr
}

\begin{abstract}
:
Seasonal snow is an active media and an important climate factor that governs nutrient transfer in Arctic ecosystems. Since the snow stores and transforms nutrients and contaminants, it is of crucial importance to gain a better understanding of the dynamics of contaminant cycling within the snowpack and its subsequent release to catchments via meltwater. Over the course of a two-month field study in the spring of 2008, we collected snow and meltwater samples from a seasonal snowpack in NyÅlesund, Norway $\left(78^{\circ} 56^{\prime} \mathrm{N}, 11^{\circ} 52^{\prime} \mathrm{E}\right)$, which were analyzed for major inorganic ions and some organic acids, as well as total, dissolved, bioavailable mercury ( $\mathrm{THg}, \mathrm{DHg}$, BioHg, respectively) and monomethylmercury $(\mathrm{MMHg})$ species. We observe a seasonal gradient for ion concentrations, with surface samples becoming less concentrated as the season progressed. A significant negative correlation between BioHg and $\mathrm{MMHg}$ was observed in the snowpack. MMHg was positively and significantly correlated to methanesulfonate concentrations. Based on these results, we propose a new model for aerobic methylation of mercury involving species in the dimethylsulfoniopropionate cycle.
\end{abstract}


For High Arctic ecosystems, snow is one of the most important climatic factors. Snow is an active media that transfers particulates and gases between the atmosphere and the landscape (Jones, 1999). It is highly photochemically active with snowpack impurities photolyzed to release reactive trace gases into the boundary layer (Grannas et al., 2007a), and, given its high albedo, fresh snow reflects as much as $90 \%$ of incoming radiation (Hinkler et al., 2008). Snow affects both the length of the growing season and primary plant production by acting as a soil insulator as well as a water and nutrient reservoir (Kuhn, 2001; Edwards et al., 2007). Atmospheric scavenging and condensation largely determine snowpack chemistry and snowpacks accumulate particles, solutes and pollutants over winter and spring (Tranter et al., 1986; Loseto et al., 2004). Once deposited, they are subject to redistribution through a variety of processes such as melt-freeze events during the winter season (Johannessen and Henriksen, 1978) and snow metamorphism (Colbeck, 1989; Kuhn, 2001). The geometry of the pore space, vapor pressure gradients and wind pressure, in addition to the physicalchemical properties of the particles themselves can also impact redistribution (Colbeck, 1989; Kuhn, 2001).

The Arctic is exposed to mercury $(\mathrm{Hg})$, a toxic metal that can be transformed to methylmercury (MeHg), a potent neurotoxin that bioaccumulates in food webs (see review by Fitzgerald et al. (2007)), through long-range atmospheric transport. Although there are no direct anthropogenic $\mathrm{Hg}$ sources in the Arctic, high levels have been found in the livers and tissues of marine mammals and birds (Wagemann et al., 1998; Campbell et al., 2005) leading to increased exposure for Native Communities that depend on these resources (AMAP, 2009). The discovery of atmospheric mercury depletion events (AMDEs) in the Arctic (Schroeder et al., 1998) led to the hypothesis that these could be the major sources of $\mathrm{Hg}$ to Arctic ecosystems. During AMDEs, atmospheric elemental mercury is oxidized to divalent mercury through reactions with halogens such as bromine radicals (Lindberg et al., 2001; Ariya et al., 2002) and then deposited onto snow surfaces at levels $400-800$ fold higher than 
background in the course of a few hours (Lu et al., 2001; Dommergue et al., 2010). Recent reports suggest that some of this newly deposited $\mathrm{Hg}$ is bioavailable, i.e. able to cross biological membranes (Scott, 2001; Lindberg et al., 2002; Larose et al., 2010), but its post-depositional fate remains unclear. Field experiments have shown that $\mathrm{Hg}$ can be both oxidized and reduced in the snowpack (Lalonde et al., 2002; Dommergue et al., 2003; Poulain et al., 2004) and there is an increasing consensus that most, but not necessarily all, of the deposited mercury is photo-reduced and reemitted back to the atmosphere (Poulain et al., 2004; Kirk et al., 2006; Dommergue et al., 2010).

In addition to the uncertainty regarding $\mathrm{Hg}$ sources to the Arctic, the mechanisms that produce MeHg in these cold environments are to date unresolved, although several pathways have been proposed. Methylation can occur both biotically and abiotically; biotic $\mathrm{Hg}$ methylation depends on microbial activity and the concentration of bioavailable mercury (BioHg) (Barkay et al., 1997), whereas abiotic methylation depends on the presence of methyl donors. These donors include small organic molecules (i.e. methyl iodide and dimethylsulfide or acetate (Hall et al., 1995; Celo et al., 2006; Hammerschmidt et al., 2007)) and larger organic components of dissolved organic matter such as fulvic and humic acids (Weber, 1993; Siciliano et al., 2005). Hence, the chemistry of the snowpack influences both $\mathrm{Hg}$ speciation and its transformation.

Since the snow stores and transforms atmospherically derived pollutants (Colbeck, 1981; Daly and Wania, 2004; Lei et al., 2004), a better understanding of the dynamics of contaminant cycling within the snowpack, and its subsequent release to catchments via meltwater would help evaluate ecotoxicological impacts. The timing and magnitude of a pulse exposure is especially important for aquatic ecosystems during spring when biological activity increasingly active (Loseto et al., 2004). The chemical concentrations at the initial stages of melt have been shown to be many times higher (3-7 fold) than averages for the entire snowpack in field and laboratory experiments, a phenomenon referred to as ionic pulse (Johannessen and Henriksen, 1978; Colbeck, 1981; Kuhn, 2001). As the snow begins to melt, soluble ions are removed by the first stages of percolation (e.g.Tranter et al., 
1986), followed by the preferential elution of some ions before others (Eichler et al., 2001). Nonpolar organic molecules are also found in meltwater, but are less easily entrained by percolating water due to their low solubility (Meyer et al., 2006). Insoluble particulate material can also be removed by percolation, but usually remains in the snow until the final stages of melting (Hodgkins, 1998; Lyons et al., 2003; Meyer et al., 2006). During spring melt, these soluble and insoluble impurities are released to the environment in a few weeks and can impact the chemistry of snowmelt-fed ecosystems (Williams et al., 2009).

Here, we present chemical data from a seasonal Arctic snowpack sampled over a two-month period in the spring of 2008 in Ny-Ålesund, Norway. The focus of this research is the storage, transfer and subsequent release of solutes and mercury from the snowpack to snowmelt-fed ecosystems. We also explore possible interactions among the different chemical parameters that could potentially be involved in mercury methylation.

\section{MATERIAL AND METHODS}

\subsection{Field site}

The spring field study was carried out between April $16^{\text {th }}, 2008$ and June $8^{\text {th }}, 2008$ at Ny-Ålesund in the Spitsbergen Island of Svalbard, Norway $\left(78^{\circ} 56^{\prime} \mathrm{N}, 11^{\circ} 52^{\prime} \mathrm{E}\right)$. The field site, a $50 \mathrm{~m}^{2}$ perimeter with restricted access (to reduce contamination from human sources), is located along the south coast of the Kongsfjorden, which is oriented SE-NW and open to the sea on the west side (Figure 1). The Kongsfjorden was free of sea ice throughout the study.

\subsection{Sampling}

Surface snow samples were collected daily for Hg speciation. Twice a week, a shallow pit was dug and both surface and basal samples were collected for ion and mercury analyses. Samples for ion measurements were collected in sterile polycarbonate vials (acuvettes ${ }^{\circledR}$ ) and stored at $-20^{\circ} \mathrm{C}$ until analysis. For $\mathrm{Hg}$ analyses, snow was collected in acid-washed $250 \mathrm{~mL}$ glass Schott bottles (see 
cleaning protocol outlined in Ferrari et al. (2000) for more details) and subsampled for dissolved and BioHg. Samples for MMHg were collected in $125 \mathrm{~mL}$ acid-washed Teflon coated low-density polyethylene bottles, and stored frozen until analysis. The bottles were hermetically sealed, doublewrapped in polyethylene bags, stored at $-20^{\circ} \mathrm{C}$, and transported frozen to the laboratory. Meltwater was collected in acid-washed $250 \mathrm{~mL}$ glass Schott bottles from streams that formed the $1^{\text {st }}$ of June, 2008. In order to determine the spatial variability in mercury deposition, we sampled two snowpits integrating snow fall since the previous summer, the first on the Holtedahlfonna glacier (sample date 30/04/08, N79 $08.17, \mathrm{E}^{\circ} 3^{\circ} 16.12,1173 \mathrm{~m}$ asl, $40 \mathrm{~km}$ from the Kongsfjorden fjord) and the second on the Kongsvegen glacier (sample date 19/05/08, N7845.29, E13²0.20, $670 \mathrm{~m}$ asl, $40 \mathrm{~km}$ from the Kongsfjorden) (Figure 1). The Holtedahlfonna pit, with a depth of $1.80 \mathrm{~m}$, was sampled at $20 \mathrm{~cm}$ intervals, whereas the Kongsvegen pit, with a depth of $2.75 \mathrm{~m}$, was sampled at $30 \mathrm{~cm}$ intervals.

Field blanks were collected, filled with ultrapure water in the laboratory, opened during sample collection, and handled as samples. To avoid contamination, Tyvex ${ }^{\circledR}$ body suits and latex gloves were worn during sampling and gloves were worn during all subsequent handling of samples.

\subsection{Chemical analyses}

\subsubsection{Total Hg \& speciation}

Total Hg (THg) in snow samples was measured in the field with a Tekran model 2600 using USEPA method 1631 revision E. Samples were oxidized with $0.5 \% \mathrm{v} / \mathrm{v} \mathrm{BrCl}$ to preserve divalent $\mathrm{Hg}(\mathrm{Hg}(\mathrm{II}))$ in solution and to digest strongly bound $\mathrm{Hg}(\mathrm{II})$ complexes. Excess $\mathrm{BrCl}$ was neutralized with pre-purified hydroxylamine hydrochloride. The sample was then automatically injected, together with $\mathrm{SnCl}_{2}$, into a reaction vessel, reducing $\mathrm{Hg}(\mathrm{II})$ to gaseous elemental $\mathrm{Hg}\left(\mathrm{Hg}^{\circ}\right) . \mathrm{Hg}^{\circ}$ was carried in an argon stream to two online gold traps. After thermal desorption, $\mathrm{Hg}^{\circ}$ was detected by atomic fluorescence spectrometry. The Tekran Model 2600 was calibrated every day with the NIST SRM-3133 Hg 
standard. The limit of detection, calculated as 10 times the standard deviation of a set of 10 blanks, was $0.3 \mathrm{ng} \cdot \mathrm{L}^{-1}$ and relative accuracy was determined as $\pm 8 \%$ using a certified reference material (ORMS-4, National Research Council Canada). All samples were analyzed in triplicate. Dissolved total $\mathrm{Hg}(\mathrm{DHg})$ concentrations were determined in all samples by measuring $\mathrm{Hg}$ concentrations after filtration on a $0.45 \mu \mathrm{m}$ nylon filter (25 mm diameter, Cole-Parmer). Bioavailable $\mathrm{Hg}$ (BioHg) concentrations were determined using the biosensor described in tarose et al. (2010). BioHg is defined as the fraction of $\mathrm{Hg}$ able to enter cells. BioHg is detected using a genetically modified bacterium containing mercury resistance and luminescence genes, such that photons are produced in a dose dependent manner upon $\mathrm{Hg}$ exposure. Briefly, the biosensor was cultured overnight in LB medium containing $100 \mu \mathrm{g} \cdot \mathrm{mL}^{-1}$ ampicillin at $37^{\circ} \mathrm{C}$ without agitation. The culture was resuspended in LB media and experiments were carried out using cells in mid-exponential growth phase $\left(\mathrm{OD}_{600}\right.$ of 0.4). Cells were exposed to either a series of $\mathrm{Hg}$ dilutions in order to obtain a standard curve, or to melted snow samples with unknown bioavailable $\mathrm{Hg}$ concentrations in a $\mathrm{v} / \mathrm{v}$ ratio (sample volume added is equal to the volume of the biosensor solution) and incubated for two hours at $37^{\circ} \mathrm{C}$ without agitation. The $\mathrm{Hg}$ standards were prepared from serial dilutions of a $\mathrm{Hg}^{2+}$ solution (SRM-3133 $\mathrm{Hg}$ standard). Samples were analyzed in triplicate, with three independent cultures, and light emission was recorded using a Modulus luminometer. Luminescence was expressed as relative light units (RLU) and normalized for optical density.

\subsubsection{Monomethylmercury analysis}

MMHg was measured on unfiltered samples as volatile methyl mercury hydride, by purge and cryotrapping gas chromatography, and detected as elemental $\mathrm{Hg}$ vapor by atomic fluorescence spectrometry (Tekran, Model 2500). The mercury hydrides (from methyl and inorganic mercury) were synthesized in the presence of $\mathrm{NaBH}_{4}$, purged from the sample with $\mathrm{He}$, concentrated and then separated by cryogenic chromatography before being converted into $\mathrm{Hg}^{0}$ in a furnace $\left(800^{\circ} \mathrm{C}\right)$ and 
detected by the AFS detector. This protocol is derived from the hydride generation technique described by Tseng et al. (1998) and improved by Stoichev et al. (2004). The hydrides are formed within a glass reactor and the column used is a silanized glass tube filled with Chromosorb W/AWDMCS impregnated with $15 \%$ OV-3. Analytical reproducibility varied with time between $6 \%$ and $15 \%$. Calibration was performed using dilutions of a $1 \mathrm{~g} \cdot \mathrm{L}^{-1}$ stock $\mathrm{MMHg}$ solution in isopropanol into an aqueous $\mathrm{HCl}$ ( $0.4 \%$ Suprapur, Merck) solution. In addition, we used certified reference material, the ERM-AE670 from the Institute for Reference Materials and Measurements (IRMM, European pmol. $L^{-1}$ of ERM-AE670 spikes in seawater samples was $103 \pm 2 \%$ and $99 \pm 2 \%$, respectively. The MMHg measurements took place within two months of sampling.

In order to determine Hg speciation within the snowpack, Vimteq simulations (Visual MINTEQ), that include parameters such as chemical equilibrium, major ions, $\mathrm{pH}$ and some short chain organic compounds, were carried out.

\subsubsection{Additional analysis}

The $\mathrm{pH}$ of melted snow samples was measured at $20^{\circ} \mathrm{C}$ (Heito $\mathrm{pH}$ meter, Paris). The electrode was manually calibrated, prior to analysis, with three different $\mathrm{pH}$ buffers ( $\mathrm{pH} 4,7$ and 10, Heito). The values were not corrected for in situ snow temperature. In order to examine possible interactions

171 between $\mathrm{Hg}$ speciation and snow chemical composition, inorganic ions ( $\mathrm{F}$ denoted $\mathrm{Fl}, \mathrm{NO}_{3}^{-}, \mathrm{Cl}^{-}, \mathrm{SO}_{4}{ }^{2-}$,

$172 \mathrm{NH}_{4}^{+}, \mathrm{Ca}^{2+}, \mathrm{Na}^{+}, \mathrm{K}^{+}$and $\mathrm{Mg}^{2+}$ ) and organic acid (methylsulfonic acid (MSA), glutaric acid (Glut), oxalic 173 acid (Ox), acetate with a possible contribution of glycolate (Ace.Glyc), and formate) concentrations were measured at the Laboratoire de Glaciologie et Géophysique de l'Environnement by conductivity-suppressed Ion Chromatography using a Dionex ICS 3000. Due to the proximity of the fjord, leading to very high chloride and sodium concentrations, samples were diluted 10 -fold for organic acids and minor ions and 100-1000 times for major ions prior to analysis. 
All data, with the exception of $\mathrm{pH}$ values, were log-transformed prior to statistical analysis in order to obtain data with a normal distribution. The transformation was successful for all data. Statistical data analysis was performed using JMP 5.1 software (SAS Institute, 2003) and R (The R Project for Statistical Computing http://www.r-project.org). Simple linear regression analysis was carried out to detect associations between the different chemicals. Principal component analysis (PCA) was performed to reduce the dimensionality of the data set using the ade4 data package for R. Samples were clustered using Ward's linkage for hierarchical cluster analysis, where the error sum of squares at each successive clustering step is minimized. Analysis of variance (ANOVA) and Tukey-Kramer HSD multiple comparison tests were then used to determine significant differences in chemical parameters among the different clusters in JMP 5.1. Statistical significance was set at a probability level $\alpha<0.05$.

\section{RESULTS}

\subsection{Snowpack dynamics}

The seasonal snowpack began to develop in October, 2007, but a rain event in January 2008 resulted in a decrease in snow depth and the formation of a relatively thick $(\sim 10 \mathrm{~cm})$ ice layer above the soil surface. The snowpack reformed above the ice layer, had a thickness of about $40 \mathrm{~cm}$ at the beginning of the sampling period $\left(16^{\text {th }}\right.$ of April), but had disappeared almost completely by the $8^{\text {th }}$ of June. Snow melt began mid-May (around the $20^{\text {th }}$ ) and meltwater rivers that flowed to the fjord formed on the $1^{\text {st }}$ of June, 2008. A total of 7 snowfall events occurred throughout the field season.

\subsection{Snowpack and meltwater chemistry}

The snowpack is strongly influenced by marine aerosols due to the proximity of the fjord, although continental sources possibly contribute to $\mathrm{Na}^{+}$and $\mathrm{Mg}^{2+}$ concentrations. The dominant cations in the 
snowpack were $\mathrm{Na}^{+}\left(1861 \mu \mathrm{mol} . \mathrm{L}^{-1}\right)$ followed by $\mathrm{Mg}^{2+}\left(426 \mu \mathrm{mol} . \mathrm{L}^{-1}\right)$ and $\mathrm{Ca}^{2+}\left(110 \mu \mathrm{mol} . \mathrm{L}^{-1}\right)$, while the dominant anions were $\mathrm{Cl}^{-}\left(2119 \mu \mathrm{mol} . \mathrm{L}^{-1}\right)$ followed by $\mathrm{SO}_{4}{ }^{2-}\left(159 \mu \mathrm{mol} . \mathrm{L}^{-1}\right)$ and $\mathrm{NO}_{3}{ }^{-}\left(5 \mu \mathrm{mol} . \mathrm{L}^{-1}\right)$. In meltwater, the average concentrations for cations and anions were 433,263 and $359 \mu \mathrm{mol} . \mathrm{L}^{-1}$ for $\mathrm{Na}^{+}, \mathrm{Mg}^{2+}, \mathrm{Ca}^{2+}$, respectively, and $569 \mu \mathrm{mol} . \mathrm{L}^{-1}$ for $\mathrm{Cl}^{-}, 90 \mu \mathrm{mol} . \mathrm{L}^{-1}$ for $\mathrm{SO}_{4}{ }^{2-}$ and $4 \mu \mathrm{mol} . \mathrm{L}^{-1}$ for $\mathrm{NO}_{3}{ }^{-}$ (Entire data ranges are given in Supplementary material Table I). In the snowpack, $\mathrm{pH}$ ranged from acidic to circumneutral values ( 4 to 6.6 ) and was stable at a pH around 6.8 in meltwater.

Based on the Vimteq results, mercury chloride $\left(\mathrm{HgCl}_{2}\right)$ is the dominant form of $\mathrm{Hg}$ complexes in all our samples, followed by $\mathrm{HgBrCl}_{1} \mathrm{HgCl}_{3}{ }^{-}, \mathrm{HgBr}_{2}$. The speciation of $\mathrm{Hg}$ is driven by the large chloride concentrations, but remains uncertain due to the lack of knowledge on binding constants of mercury with organic matter and the lack of robust speciation data of organic matter in snow. The presence of Hg complexes bound to organic compounds could readily change the photoreactivity and bioavailability of these complexes.

We performed PCA analysis and then clustered the samples using Ward's linkage. The clustering results are presented in Table I and the PCA is presented in Figure 2. Seasonality is apparent, since Group 1 comprises early season surface samples and most of the basal samples, Group 2 contains mid-season surface samples, Group 3 contains late-season surface samples, and Group 4 is composed of meltwater samples. Although precipitation events occurred at different times throughout the field season, they had no effect on sample distribution within the PCA, since samples collected during snowfall events did not cluster together. In the graphical representation of the PCA analysis, the length of the arrow represents the relative importance of the associated parameter in determining the distribution of samples. Based on the PCA analysis carried out on our data, the most important parameters driving sample distribution are BioHg and THg (Group 1), MMHg, MSA and Glut (Group 2), inorganic ions (Group 5) and certain organic acids (Group 4). The clustering of samples in Group 3 is driven by low concentrations of inorganic ions and organic acids. 
ANOVA and multiple comparison tests were carried out in order to determine significant differences

in chemical parameters among the five groups derived through PCA analysis and clustering using

Ward's linkage. The results of these comparisons are presented in Table I (Supplementary material).

Chemical parameters varied significantly among groups, with the exception of $\mathrm{THg}$, $\mathrm{DHg}$ and $\mathrm{BioHg}$

(data not shown) (Table I, Supplementary material). There appears to be a seasonal gradient, with

early season snow (Group 1) that is generally more concentrated than snow sampled later in the

season (Groups 2 and 3). Meltwater (Group 4) is enriched in ions relative to snow, with the exception

of the five snow samples in Group 5 that had the highest mean $\mathrm{Na}^{+}, \mathrm{NH}_{4}^{+}, \mathrm{K}^{+}, \mathrm{Mg}^{2+}, \mathrm{Cl}^{-}, \mathrm{SO}_{4}{ }^{2-}$ and $\mathrm{Br}^{-}$ concentrations. Group 5 and Group 4 had the highest $\mathrm{Ca}^{2+}$ concentrations, and Group 4 had the highest levels of $\mathrm{NO}_{2}^{-}$and organics.

Group 2 had the highest $\mathrm{NO}_{3}{ }^{-}$concentrations and Groups 2 and 4 had the highest MSA and glutaric acid levels. MSA and glutaric acid levels peaked in surface samples during May (Figure 3) and are significantly and positively correlated $\left(r^{2}=0.62, p=0.0013, n=13\right)$. There are no significant differences among the groups in terms of $\mathrm{Na}: \mathrm{Cl}$ and $\mathrm{Br}: \mathrm{Cl}$ ratios, and the mean values of these ratios are close to those of seawater $(\mathrm{Na}: \mathrm{Cl}=0,855$ and $\mathrm{Br}: \mathrm{Cl}=0,0015)$. The meltwater group has significantly higher $\mathrm{K}: \mathrm{Cl}$ and $\mathrm{Mg}: \mathrm{Cl}$ ratios ( 0.052 and 0.474 , respectively) than the other groups, for which the ratios are similar to seawater ( $\mathrm{K}: \mathrm{Cl}=0.0186$ and $\mathrm{Mg}: \mathrm{Cl}=0.193)$. Group 5 had the lowest $\mathrm{Ca}: \mathrm{Cl}$ ratio, which is close to the seawater ratio $(0.044)$, while the other groups had significantly higher values. The $\mathrm{SO}_{4}: \mathrm{Cl}$ ratio was highest in Group 2 at 0.430, and was closest to the seawater ratio (0.103) in Groups 5 and 1.

Meltwater samples were collected as of the $1^{\text {st }}$ of June. The first sample collected had the highest $\mathrm{Na}^{+}, \mathrm{Cl}^{-}, \mathrm{K}^{+}, \mathrm{Mg}^{2+}, \mathrm{SO}_{4}{ }^{2-}$ and MSA concentrations (Figure 4) and appears to correspond to the tail-end of the ionic pulse. Glutaric acid, $\mathrm{NO}_{3}{ }^{-}$and $\mathrm{NO}_{2}{ }^{-}$concentrations increased as melting progressed and no peak in $\mathrm{Br}^{-}$and $\mathrm{NH}_{4}{ }^{+}$concentrations was observed. $\mathrm{MMHg}$ concentrations were highest in the first meltwater sample ( $1^{\text {st }}$ of June), whereas concentrations of BioHg, DHg and THg peaked on the $2^{\text {nd }}, 6^{\text {th }}$ and $7^{\text {th }}$ of June, respectively (Figure 4). 


\subsection{Hg dynamics}

252 At the onset of sampling (April $16^{\text {th }}, 2008$ ), surface snow had high THg concentrations, with levels 253 reaching almost $90 \mathrm{ng} \cdot \mathrm{L}^{-1}$. These concentrations dropped to around 1 or $2 \mathrm{ng} \cdot \mathrm{L}^{-1}$ by the $9^{\text {th }}$ of May and 254 increased again just prior to melt. THg concentrations in basal snow were relatively low at the 255 beginning of the sampling period and increased gradually to levels above those of the surface around 256 the $9^{\text {th }}$ of May. THg concentrations in both basal and surface snow increased slightly from the $17^{\text {th }}$ to 257 the $23^{\text {rd }}$ of May (Figure 3). BioHg concentrations were higher in surface samples than basal samples and peaked at the beginning and end of the sampling period (Figure 3). No MMHg data for surface samples was available between April $16^{\text {th }}$ and May $6^{\text {th }}$ since THg concentrations were too elevated to allow the detection of the MMHg peak with our analytical setup, but as of May $9^{\text {th }}$, concentrations were around $0.045 \mathrm{ng} \cdot \mathrm{L}^{-1}$ and dropped progressively to about $0.010 \mathrm{ng} \cdot \mathrm{L}^{-1}$ by May $25^{\text {th }}$. Two large MMHg peaks were measured in surface snow on the $21^{\text {th }}$ and $27^{\text {th }}$ of May with concentrations reaching 0.299 and $0.511 \mathrm{ng} \cdot \mathrm{L}^{-1}$, respectively. Basal snow MMHg levels were measured throughout the field period and concentrations were low, averaging $0.010 \mathrm{ng} \cdot \mathrm{L}^{-1}$, with the exception of a peak $\left(0.245 \mathrm{ng} \cdot \mathrm{L}^{-1}\right)$ on the $2^{\text {nd }}$ of June (Figure 3 ).

Linear regression analysis was carried out to explore the relationship between different $\mathrm{Hg}$ species and the major parameters influencing sample distribution as determined by PCA analysis. No significant linear correlations were obtained between $\mathrm{MMHg}$ and $\mathrm{SO}_{4}{ }^{2-}, \mathrm{NO}_{3}{ }^{-}$or $\mathrm{Cl}^{-}$concentrations when samples were analyzed either together, by group or based on sampling depth. THg concentrations were correlated to $\mathrm{Cl}^{-}$concentrations in surface samples $\left(r^{2}=0.31, p=0.0032, n=26\right)$ and basal samples $\left(r^{2}=0.31, p=0.039, n=14\right)$. Based on PCA analysis, MMHg and MSA concentrations are correlated, and both are anti-correlated to BioHg concentrations. MSA, MMHg and glutaric acid also appear to be correlated (Figure 2). Linear regression analysis was carried out to determine the

274 significance of these relationships and $\mathrm{MMHg}$ and MSA are significantly, positively correlated $275\left(r^{2}=0.45, p=0.0022, n=18\right)$, as are Glut and MSA $\left(r^{2}=0.62, p=0.0013, n=13\right)$, but there is no significant 
276 linear relationship between $\mathrm{MMHg}$ and Glut $\left(r^{2}=0.02, p=0.70, n=9\right)$. MMHg and BioHg are

277 significantly, negatively correlated in the snowpack $\left(r^{2}=0.26, p=0.0044, n=26\right)$, as are BioHg and MSA $278\left(r^{2}=0.52, p=0.0018, n=15\right)$, while no significant relationship exists between BioHg and Glut $\left(r^{2}=0.08\right.$, $279 p=0.47, n=8)$.

THg and $\mathrm{MMHg}$ concentrations in glacier snowpits are presented in Figure 5. THg in both pits decreased rapidly with depth, with buried layers showing low or undetectable values. Both pits exhibit similar MMHg patterns with the highest concentrations at the surface, decreasing over the first $50 \mathrm{~cm}$, then increasing to a peak at $\sim 150 \mathrm{~cm}$, and decreasing below. In the Kongsvegen pit (Figure 5), unlike the Holtedahlfonna pit, MMHg levels increased again in the lowest part of the pit. Organics (MSA, glutaric acid) could only be detected in surface and bottom layers while $\mathrm{SO}_{4}: \mathrm{Cl}, \mathrm{Na}: \mathrm{Cl}$ and $\mathrm{Br}: \mathrm{Cl}$ ratios were similar to seawater. $\mathrm{Mg}: \mathrm{Cl}, \mathrm{K}: \mathrm{Cl}$ and $\mathrm{Ca}: \mathrm{Cl}$ ratios were much higher than those of seawater. The detailed chemistry for both pits is given in Table II. No significant correlations were observed between $\mathrm{MMHg}$ and $\mathrm{Hg}$, or between $\mathrm{Hg}$ species and ion concentrations.

\section{DISCUSSION}

\subsection{Snowpack and meltwater chemical composition}

The snowpack evolves chemically over time. We observe a seasonal gradient in ion concentrations in the snowpack, with the highest concentrations for most ions observed in early season surface and basal snow (Group 1), whereas the lowest concentrations were observed in samples collected in late spring, just prior to melt (Group 3). Melting can occur at air temperatures below $0^{\circ} \mathrm{C}$ when solar radiation is sufficiently intense and penetrates into the snowpack (Kuhn, 1987). As a result, the top snow layers melt first and the surface layers gradually become less concentrated in ions and particles as the season progresses. The photochemical reactivity of surface layers also contributes to changes in ion concentrations, with snowpack impurities photolyzed to release reactive trace gases such as 
$\mathrm{NO}_{2}, \mathrm{HONO}, \mathrm{CH}_{2} \mathrm{O}, \mathrm{BrO}$ and $\mathrm{Hg}^{0}$ to the boundary layer. These processes appear to be ubiquitous and their influence varies according to background radical concentrations (Grannas et al., 2007b).

301 Our results are consistent with those of Goto-Azuma et al. (1994) who observe higher ion concentrations at the base of an Arctic snowpack as a result of percolation and snowpack metamorphism. The surface and basal samples in Group 5 had the highest ion concentrations among all groups, including the meltwater group. This is surprising since meltwater mobilizes solutes and contaminants within the snowpack, thus becoming enriched relative to the snow (Kuhn, 2001; Meyer and Wania, 2008). The samples in Group 5 carry a strong marine salt signal, as determined by the different ion to $\mathrm{Cl}^{-}$ratios (Table I, Supplementary material). It is likely that the surface sample of this group (sample date 19/04/2009) contained sea-spray and was enriched by marine air masses. The signal of this event can later be traced in the basal samples following snowfall and elution. It is also possible that the highly concentrated basal samples consist of older snow that had undergone similar deposition events from marine air masses.

Mid-season surface snow samples (Group 2, May $9^{\text {th }}$ to May $30^{\text {th }}$ ) had high levels of glutaric acid, MSA and $\mathrm{NO}_{3}{ }^{-}$, in addition to the highest $\mathrm{SO}_{4}{ }^{2-}$ to $\mathrm{Cl}^{-}$ratio among all groups. Glutaric acid, a $\mathrm{C}_{5}$ dicarboxylic acid commonly found in aerosols and as cloud-condensation nuclei, is derived from a variety of sources including anthropogenic emissions such as motor exhaust, as well as biogenic emissions from the ocean (Kawamura and Ikushima, 1993; Kawamura and Kasukabe, 1996). Senescent marine phytoplankton cells release lipidic cell components (chlorophyll, chlorophyll phytyl chain, carotenoids, sterols, and unsaturated fatty acids (oleic acid, alkenones and unsaturated alkenes) (Rontani, 2001) that can be photooxidized to shorter diacids. Among the diacids, oxalic acid is generally the most abundant in aerosols, followed by succinic, malonic and glutaric acid (Kawamura and Kasukabe, 1996). This has been observed in diverse environments worldwide, including the Arctic. Another pathway involved in diacid production is the reaction of $\mathrm{O}_{3}$ with cyclohexene, a symmetrical alkene molecule (Rontani, 2001). Hence, diacids in the marine environment originate 
from two major processes: long-range transport from industrialized continents and in situ

325 photochemical production. Legrand et al. (2007) reported seasonal differences in diacid

326 concentrations in aerosols of a coastal site, with high oxalic acid and low $C_{5}$ and $C_{4}$ concentrations in

327 the winter. They proposed that ageing of air masses during transport favored the production of

328 short-chain diacids through the successive oxidation of $C_{5}$ and $C_{4}$ diacids. This is consistent with our

329 data, as the early season snow oxalic acid in the first sample of Group 5 seems to originate from

330 older marine air masses that travelled over the Arctic Ocean (HYSPLIT air mass trajectory model, data

331 not shown). Glutaric acid was almost undetectable at the beginning of the season, but

332 concentrations were high in samples from Group 2 collected in surface snow during the month of

333 May. In the summer, Legrand et al. (2007) reported peak concentrations of $C_{5}$ and $C_{4}$ acids in a mid-

334 latitude marine atmosphere, which may be attributed to unsaturated fatty acid degradation. The

335 high glutaric acid concentrations relative to oxalic acid in our data set suggest that fatty acids

336 originated from proximal marine emissions as the succession of oxidations to shorter diacids did not

337 lead to total $\mathrm{C}_{5}$ and $\mathrm{C}_{4}$ depletion. Glutaric acid is also significantly positively correlated to MSA, which

338 further supports the presence of a close marine source of organic acids. MSA is a photo-oxidation

339 product of DMS, which itself is a derivative of dimethylsulphoniopropionate (DMSP) produced by

340 phytoplankton (Bentley and Chasteen, 2004). DMSP is known as both an osmoprotectant and

341 cryoprotectant for microorganisms, as well as a carbon and sulfur source. It is released from

342 senescent or stressed cells (Kiene et al., 2000). MSA has been shown to exhibit a distinct seasonality

343 that is linked to biological activity in Arctic waters and the importance of the phytoplankton bloom to

344 dimethylsulfate (DMS) concentrations has also been reported (Leck and Persson, 1996). The most

345 recent published data available on algae blooms in Svalbard were collected in 2007 and show that

346 the bloom occurred in May (Narcy et al., 2009). Although the data for the 2008 period are

347 unavailable, it is likely that the bloom occurred at the same period of the year. 
The chemical changes of a snowpack and runoff are influenced by the chemical composition of the snow and wintertime refreezing processes of the meltwater (Colbeck, 1981; Davies et al., 1982; Bales et al., 1993). The first flush of meltwater is usually highly concentrated, with the preferential elution of certain solutes over others leading to a pulse (Colbeck, 1981; Goto-Azuma et al., 1994). Meltwater samples had mean ion concentrations that were comparable to those reported for early seasonal snow (Group 1), with the exception of $\mathrm{K}^{+}, \mathrm{Mg}^{2+}$ and $\mathrm{Ca}^{2+}$ concentrations, which were much higher. In addition, the $\mathrm{Mg}: \mathrm{Cl}, \mathrm{K}: \mathrm{Cl}$ and $\mathrm{Ca}: \mathrm{Cl}$ were also significantly higher than in the early season samples. These elevated ratios may reflect the contact between the meltwater and the soil, since meltwater can be modified by soil processes due to infiltration and leaching (Williams et al., 2009) in addition to the flushing of soil pore fluids upon soil thaw. Although solute concentrations in the first meltwater sample are high, it is likely that the pulse occurred before the formation of meltwater rivers and that we only measured the tail-end of the pulse, since we were unable to detect preferential elution. Nevertheless, we did observe some fractionation of mercury species, as MMHg was preferentially eluted to $\mathrm{BioHg}$, followed by the dissolved fraction. The chemical composition of the $\mathrm{DHg}$ fraction is unknown, but likely consists of different forms of $\mathrm{Hg}$ that are soluble, but not bioavailable. The remaining $\mathrm{Hg}$ was eluted last and was probably bound to insoluble particles (Figure 4).

\subsection{Snowpack Hg dynamics}

While AMDEs have been shown to lead to high deposition of $\mathrm{Hg}$ onto snow surfaces, the postdepositional fate of $\mathrm{Hg}$ has yet to be completely clarified. The current consensus among researchers now is that a large portion is reemitted back to the atmosphere following an event (Poulain et al., 2004; Kirk et al., 2006; Dommergue et al., 2010). We recorded an AMDE at the beginning of the field season that led to high concentrations in the snowpack (max value $90 \mathrm{ng} . \mathrm{L}^{-1}$ ), but these decreased

371 rapidly. At the beginning of the field season, basal snow sample $\mathrm{Hg}$ concentrations were low, around

372 1-2 ng. $\mathrm{L}^{-1}$, yet they increased almost 8-fold following the AMDE-induced peak in surface snow 
concentrations. Although the transfer mechanisms that lead to this increase are unclear, $\mathrm{Hg}$ was likely transferred into deeper layers of the snowpack from the surface bound to particulate matter or as a mobile chemical form that percolated through the snowpack (Daly and Wania, 2004; Johnson et al., 2008). If the $\mathrm{Hg}$ levels in the basal layers of the snow result from AMDEs, then the quantity retained by the snowpack represents roughly $10 \%$ of the initial loading. These results suggest that although a large portion of $\mathrm{Hg}$ deposited by AMDEs returns to the atmosphere, a significant quantity is trapped within the snowpack, from which it can then be transferred to other systems upon melting.

In a review on $\mathrm{Hg}$ microbiogeochemistry in polar environments, Barkay and Poulain (2007) outline possible methylmercury sources and methylation pathways in arctic ecosystems. These include atmospheric and aquatic sources with either abiotic or biotic methylation pathways. In terms of snowpack MMHg concentrations, the most plausible sources are: 1) an atmospheric source of $\mathrm{MMHg}$ due to the photodegradation and deposition of plankton-derived dimethylmercury, 2) in situ methylation of BioHg in the snowpack (microbial), 3) biotic or abiotic methylation in the atmosphere, and 4) in situ phytoplankton MMHg production.

Based on a positive correlation between MMHg and chloride in snow collected from Ellesmere Island, Nunavut, Canada, St. Louis et al. (2005) suggested that MMHg was bound to seasalt aerosols (i.e. source 1). Constant et al. (2007) also reported a similar correlation in subarctic snow. This led to the hypothesis that $\mathrm{MMHg}$ originated from gaseous dimethylmercury ( $\mathrm{DMHg}$ ) formed by phytoplankton in the water column, whose production has been reported in Arctic waters (Kirk et al., 2008). Since DMHg is highly volatile, it can be emitted from the seawater and be oxidized to $\mathrm{MMHg}$ in the atmosphere by free radical species such as $\mathrm{OH}^{\circ}$ And Cl (Niki et al., 1983a; Niki et al., 1983b) before being deposited onto nearby snow surfaces (St. Louis et al., 2005). However, no correlation between MMHg and chloride was observed in our data set, even when the different snow types and groups are analyzed individually. St Louis et al. (2007) also observed a lack of correlation between MMHg 

and chloride, but still attributed $\mathrm{MMHg}$ concentrations to $\mathrm{DMHg}$ production and subsequent photodegradation based on the proximity of their sampling sites to the water.

MMHg is significantly anti-correlated to BioHg in our snow samples, which could suggest that a fraction of the BioHg is efficiently scavenged to form $\mathrm{MMHg}$. Bacteria have been isolated from Arctic snowpacks (Amato et al., 2007) and microbial activity has been measured at temperatures down to $20^{\circ} \mathrm{C}$ (Christner, 2002). Poulain et al. (2007) reported the presence of $\mathrm{Hg}$ resistance (merA) gene transcripts in Arctic biofilm samples and, hence, it is likely that the microbial populations in Arctic environments are able to metabolize mercury. Whether $\mathrm{Hg}$ methylation can occur in the snow remains uncertain. Constant et al. (2007) reported increases in the MMHg:THg ratio that were positively correlated with bacterial colony counts and particles. These results led to the hypothesis that $\mathrm{MMHg}$ was being formed within the snowpack, despite the absence of correlation with sulfatereducing bacteria $(\mathrm{SRB})$, the principal methylators in anoxic environments. Since the snowpack is most likely oxygenated, other species capable of methylating Hg aerobically may exist.

Hg methylation has been linked to sulfur and iron metabolism in bacteria (Fleming et al., 2006; Kerin et al., 2006). Early research into the mechanisms of $\mathrm{Hg}$ methylation was based on anoxic sediments (Compeau and Bartha, 1985; Berman et al., 1990) and quickly focused on anaerobic, sulfate reducing bacteria. Choi et al. (1994) used radio-labeled ${ }^{14} \mathrm{C}$ incorporation and enzyme activity measurements to propose that methylation involves the tetrahydrofolate (THF) pathway in Desulfovibrio desulfuricans. In their model, the methyl group is transferred from $\mathrm{CH}_{3}$-tetrahydrofolate via methylcobalamin with either serine or formate as the original methyl donors during the acetyl-CoA synthase pathway.

In our samples, MMHg is positively correlated to MSA, a by-product of DMSP and an important molecule in the marine microbial sulfur cycle (Kiene et al., 2000). DMSP can be metabolized via several different pathways in the water column (Figure 6), one involving enzymatic cleavage to produce DMS, but also by demethylation and demethiolation to produce methylsulfate in bacterial 
cells. Methylsulfate can then undergo thiol transmethylation to produce DMS (Bentley and Chasteen, 2004). The initial demethylation (and a possible second demethylation) has recently been shown to be THF-dependent and catalyzed by an amino-methyltransferase enzyme in aerobic bacteria (Reisch et al., 2008). The similarities to anaerobic $\mathrm{Hg}$ methylation are striking, and it is possible that a fraction of $\mathrm{BioHg}$, upon entering the cell, undergoes methylation by aerobic bacteria that are able to demethylate or metabolize DMSP. A total of four methyl transfer reactions occur at various stages of DMSP metabolism, and BioHg may serve as a methyl group acceptor at some point in the process. BioHg is also negatively correlated to MSA, which further suggests DMSP implication (or the implication of another product of DMSP metabolism) in the methylation of $\mathrm{Hg}$. This is compounded by the fact that neither MMHg nor BioHg concentrations are significantly correlated to glutaric acid, a biogenically produced dicarboxylic acid. Finally, this hypothesis is reinforced by recent results demonstrating $\mathrm{Hg}$ methylation in the oxic oceanic water column (Monperrus et al., 2007; Cossa et al., 2009; Sunderland et al., 2009).

Whether methylation occurs within the snowpack, in the water column or both simultaneously remains under debate, but, methylation appears to require a substrate involved in DMSP cycling. Hence, coastal sites may be especially at risk for $\mathrm{MMHg}$ contamination, since they are reported to contain higher Hg concentrations than inland sites (Douglas and Sturm, 2004; Brooks et al., 2008) and are close to a DMSP source. In addition, the run-off during springtime melt may return concentrated water back to the aquatic ecosystem.

Although the case for biologically-produced MMHg is strong, the data from the snow pits sampled on April $30^{\text {th }}$ and May $19^{\text {th }}$ point to a combination of sources for MMHg in remote areas. Since the fjord is $40 \mathrm{~km}$ away from both sampling sites, its effect on the chemical composition of snow is less important, as reflected by the 1-3 order of magnitude lower $\mathrm{Na}^{+}$and $\mathrm{Cl}^{-}$concentrations measured in our pit samples. MMHg concentrations were generally higher than in the surface waters of the fjord (seasonal average $10 \pm 4 \mathrm{pg} \cdot \mathrm{L}^{-1}$ ) and higher than average MMHg levels in the seasonal snowpack, 
excluding the peaks measured towards the end of May. In addition, BioHg and MSA concentrations were generally below detection limit in these samples, which would exclude the biotic methylation mechanism outlined above. THg levels were also low, and neither THg nor MMHg were significantly correlated to $\mathrm{Cl}^{-}$concentrations. Taken together, these results suggest alternate sources for $\mathrm{MMHg}$. Abiotic methylation may be occurring in the atmosphere and involve methyl donors such acetate and reactive mercury (not strongly bound) in the aqueous phase, as proposed by Hammerschmidt et al. (2007). Methylation kinetics obtained by Gardfeldt et al. (2003) suggest a reaction pathway where $\mathrm{Hg}(\mathrm{II})$ is bound to organic complexes. Nevertheless, this does not exclude an oceanic source for $\mathrm{MMHg}$, since the layers with marine organics also exhibit the highest $\mathrm{MMHg}$ concentrations. Finally, the elevated levels of $\mathrm{MMHg}$ in the Kongsvegen basal layer may point to biotic methylation. Amato et al. (2007) found higher concentrations of bacteria in the summer layer in a pit dug on the same glacier and this may reflect microbial growth and metabolism. These potential sources of MMHg may have been masked at the coastal site by the influence of the fjord. It is likely that MMHg is supplied to Arctic environments by various pathways that are occurring simultaneously.

\section{Acknowledgements}

This work is funded by EC2CO, LEFE-CHAT and by the French Polar Institute IPEV for logistical support (program CHIMERPOL). We acknowledge Alan Le Tressoler and AWIPEV for field support, as well as Emmanuel Prestat for advice on statistics and I. Moreno and J. Cozic for their help in the laboratory. We would also like to thank M. Legrand for the scientific discussions. CL would like to acknowledge the FQRNT (le Fond Québécois de la Recherche sur la Nature et les Technologies) for a PhD research fellowship. 
472 Table I: Groups, corresponding samples and sample dates as derived by PCA analysis and Ward's 473 linkage for hierarchical clustering analysis

\begin{tabular}{|c|c|c|}
\hline Cluster name & Nature of the sample & date \\
\hline Group 1 & $\begin{array}{l}\text { Early season surface snow and } \\
\text { most of basal snow samples }\end{array}$ & $16 / 04 / 08$ to $06 / 05 / 2008$ \\
\hline Group 2 & Mid-season surface snow & $09 / 05 / 2008$ to $30 / 05 / 2008477$ \\
\hline Group 3 & Late-season surface snow & 01/06/2008 to $8 / 06 / 2008$ \\
\hline Group 4 & Meltwater samples & $01 / 06 / 2008$ to $08 / 06 / 2008^{478}$ \\
\hline Group 5 & $\begin{array}{l}\text { An early surface sample and four } \\
\text { basal samples }\end{array}$ & $\begin{array}{ll}\text { 19/04/2008, 23/04/2008, } & \\
\text { 29/04/2008, 09/05/2008, } \\
\text { 20/05/2008 }\end{array}$ \\
\hline
\end{tabular}

481

482

483

484 
488
Table II: Measured species concentrations at different depths at the Holtedahlfonna $(\mathrm{H})$ and Kongsvegen (K) snowpits. Ion concentrations are expressed in $\mu \mathrm{mol} . \mathrm{L}^{-1}$. Standard error was less than $10 \%$.

\begin{tabular}{|l|l|l|l|l|l|l|l|l|l|l|l|}
\hline $\begin{array}{l}\text { Snow } \\
\text { sample }\end{array}$ & $\mathrm{MSA}$ & $\mathrm{Cl}^{-}$ & $\mathrm{Br}$ & $\mathrm{NO}_{3}^{-}$ & $\mathrm{Glut}$ & $\mathrm{SO}_{4}^{2-}$ & $\mathrm{Na}^{+}$ & $\mathrm{NH}_{4}^{+}$ & $\mathrm{K}^{+}$ & $\mathrm{Mg}^{++}$ & $\mathrm{Ca}^{++}$ \\
\hline $\mathrm{H} 0 \mathrm{~cm}$ & 0.12 & 5.6 & 0.00 & 1.3 & 0.03 & 5.4 & 5.4 & 1.6 & 0.13 & 1.8 & 1.8 \\
\hline $\mathrm{H} 20 \mathrm{~cm}$ & 0.00 & 18.1 & 0.22 & 0.6 & 0.00 & 1.8 & 17.3 & 0.6 & 0.19 & 3.9 & 1.8 \\
\hline $\mathrm{H} 40 \mathrm{~cm}$ & 0.00 & 62.4 & 0.52 & 3.1 & 0.00 & 8.4 & 56.8 & 2.2 & 0.89 & 16.3 & 4.8 \\
\hline $\mathrm{H} 60 \mathrm{~cm}$ & 0.00 & 35.8 & 0.43 & 0.8 & 0.00 & 3.5 & 32.9 & 1.2 & 0.38 & 11.3 & 3.8 \\
\hline $\mathrm{H} 80 \mathrm{~cm}$ & 0.00 & 46.2 & 0.43 & 0.7 & 0.00 & 4.7 & 37.8 & 1.1 & 0.37 & 12.6 & 2.7 \\
\hline $\mathrm{H} 100 \mathrm{~cm}$ & 0.00 & 7.3 & 0.09 & 0.5 & 0.00 & 1.9 & 6.5 & 0.7 & 0.08 & 2.5 & 1.7 \\
\hline $\mathrm{H} 120 \mathrm{~cm}$ & 0.00 & 22.0 & 0.22 & 0.7 & 0.00 & 2.1 & 19.4 & 1.3 & 0.29 & 6.4 & 1.9 \\
\hline $\mathrm{H} 140 \mathrm{~cm}$ & 0.00 & 14.6 & 0.13 & 0.4 & 0.00 & 1.5 & 14.0 & 0.4 & 0.15 & 4.3 & 1.4 \\
\hline $\mathrm{H} 160 \mathrm{~cm}$ & 0.00 & 0.9 & 0.00 & 0.4 & 0.00 & 0.6 & 0.8 & 0.5 & 0.03 & 0.3 & 0.9 \\
\hline $\mathrm{H} 180 \mathrm{~cm}$ & 0.12 & 3.7 & 0.00 & 1.6 & 0.00 & 2.3 & 0.8 & 0.8 & 0.09 & 4.1 & 3.8 \\
\hline $\mathrm{K} 0 \mathrm{~cm}$ & 1.66 & 13.5 & 0.22 & 3.1 & 0.07 & 16.1 & 12.0 & 4.7 & 0.11 & 5.9 & 4.7 \\
\hline $\mathrm{K} 30 \mathrm{~cm}$ & 0.00 & 15.1 & 0.22 & 0.6 & 0.01 & 2.6 & 13.7 & 0.6 & 0.15 & 5.2 & 1.9 \\
\hline $\mathrm{K} 60 \mathrm{~cm}$ & 0.00 & 39.0 & 0.30 & 2.0 & 0.00 & 5.7 & 38.4 & 1.0 & 0.35 & 11.7 & 3.3 \\
\hline $\mathrm{K} 90 \mathrm{~cm}$ & 0.00 & 100.4 & 0.90 & 1.0 & 0.00 & 10.8 & 85.7 & 1.0 & 1.37 & 28.1 & 6.4 \\
\hline $\mathrm{K} 120 \mathrm{~cm}$ & 0.00 & 34.2 & 0.34 & 1.1 & 0.00 & 3.2 & 34.7 & 0.4 & 0.40 & 10.3 & 2.1 \\
\hline $\mathrm{K} 150 \mathrm{~cm}$ & 0.00 & 21.3 & 0.22 & 0.9 & 0.00 & 4.4 & 19.9 & 1.0 & 0.26 & 6.7 & 2.5 \\
\hline $\mathrm{K} 180 \mathrm{~cm}$ & 0.00 & 46.4 & 0.47 & 0.5 & 0.00 & 5.3 & 40.5 & 1.3 & 0.45 & 17.0 & 3.3 \\
\hline $\mathrm{K} 210 \mathrm{~cm}$ & 0.00 & 25.9 & 0.30 & 0.9 & 0.01 & 3.6 & 25.5 & 1.2 & 0.35 & 9.1 & 4.6 \\
\hline $\mathrm{K} 240 \mathrm{~cm}$ & 0.10 & 12.0 & 0.13 & 0.5 & 0.03 & 3.6 & 12.2 & 0.9 & 0.17 & 5.7 & 3.3 \\
\hline $\mathrm{K} 270 \mathrm{~cm}$ & 0.02 & 6.9 & 0.13 & 0.1 & 0.00 & 0.4 & 5.4 & 0.5 & 0.10 & 1.3 & 0.6 \\
\hline
\end{tabular}




\section{FIGURE CAPTION}

Figure 1: Map of the study area. Left map: Location of the Svalbard Archipelago. Right map: NyÅlesund (black star), Svalbard (Norway) and its surroundings. Sampling sites on the glaciers are shown with black triangles.

Figure 2: Principal component analysis for the sampling period. Chemical data ( $\mu \mathrm{mol} . \mathrm{L}^{-1}$ or $\mathrm{ng} . \mathrm{L}^{-1}$ for Hg species) were log-transformed prior to analysis. The data set covers the entire sampling period $\left(16^{\text {th }}\right.$ April- June $\left.8^{\text {th }}\right)$. Abbreviations: Glut=glutaric acid, MSA=methanesulfonic acid, Ox=oxalic acid, For=formate, F=fluoride, Ace.Glyc=acetate-glycolate, BioHg=bioavailable $\mathrm{Hg}, \mathrm{THg}=\mathrm{total} \mathrm{Hg}$, MeHg=monomethylmercury, $\mathrm{DHg}=$ dissolved total $\mathrm{Hg}$

Figure 3: Chemical profiles over time for organics (MSA, glutaric acid, oxalic acid) and different mercury species. Organic concentrations are expressed in $\mu \mathrm{mol} . \mathrm{L}^{-1}$, total mercury (THg) and bioavailable mercury (BioHg) are expressed in ng. $\mathrm{L}^{-1}$. Monomethylmercury (MMHg) concentrations are expressed in pg. $\mathrm{L}^{-1}$. Full squares represent surface samples, open squares represent basal samples and crosses are meltwater samples. Surface samples for MMHg and HgT are presented on a log-scale. All analyses were carried out in duplicate or triplicate and standard error was less than $10 \%$.

Figure 4: Meltwater elution curves for major ions and different mercury species over time. Ion concentrations are expressed in $\mu \mathrm{mol}^{-\mathrm{L}^{-1}}$, total $(\mathrm{THg})$, dissolved total (DHg) and bioavailable (BioHg) mercury concentrations are expressed in $\mathrm{ng} \cdot \mathrm{L}^{-1}$. Monomethylmercury $(\mathrm{MMHg})$ concentrations are in pg. $\mathrm{L}^{-1}$. Analyses were carried out in duplicate or triplicate and standard error was less than $10 \%$. 
520 Figure 5: Snowpit total mercury (THg) and monomethylmercury (MMHg) profiles for Holtedahlfonna

521 (sample date 30/04/2008) and Kongsvegen (sample date 19/05/2008) glaciers.

522

523 Figure 6: Sulfur cycle (modified from Bentley and Chasteen (2004)). The pathways represented here

524 focus on biogenic transformations and the numbered pathways represent those discussed in the

525 text. Other transformations occur but are not addressed in this paper. The pathways are: 1) DMSP-

526 Iyase. 2) Demethylation. 3) MMPA demethylation. 4) Thiol transmethylation. 5) Thiol

527 transmethylation. The star symbol represents reactions where BioHg could potentially be methylated

528 through methyltransfer reactions. 


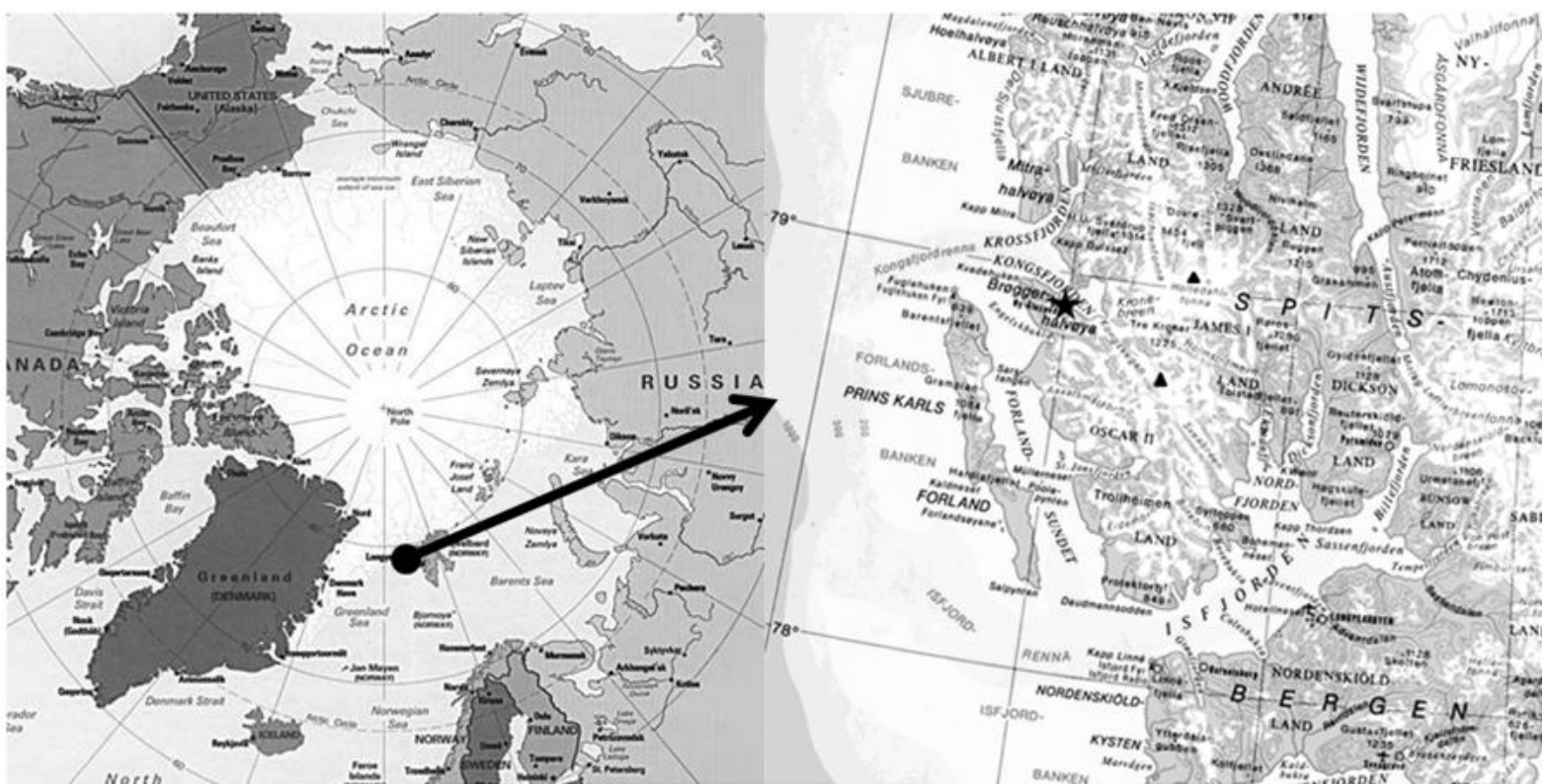

Figure 1: Map of the study area. Left map: Location of the Svalbard Archipelago. Right map: Ny-

Ålesund (black star), Svalbard (Norway) and its surroundings. Sampling sites on the glaciers are shown with black triangles. 


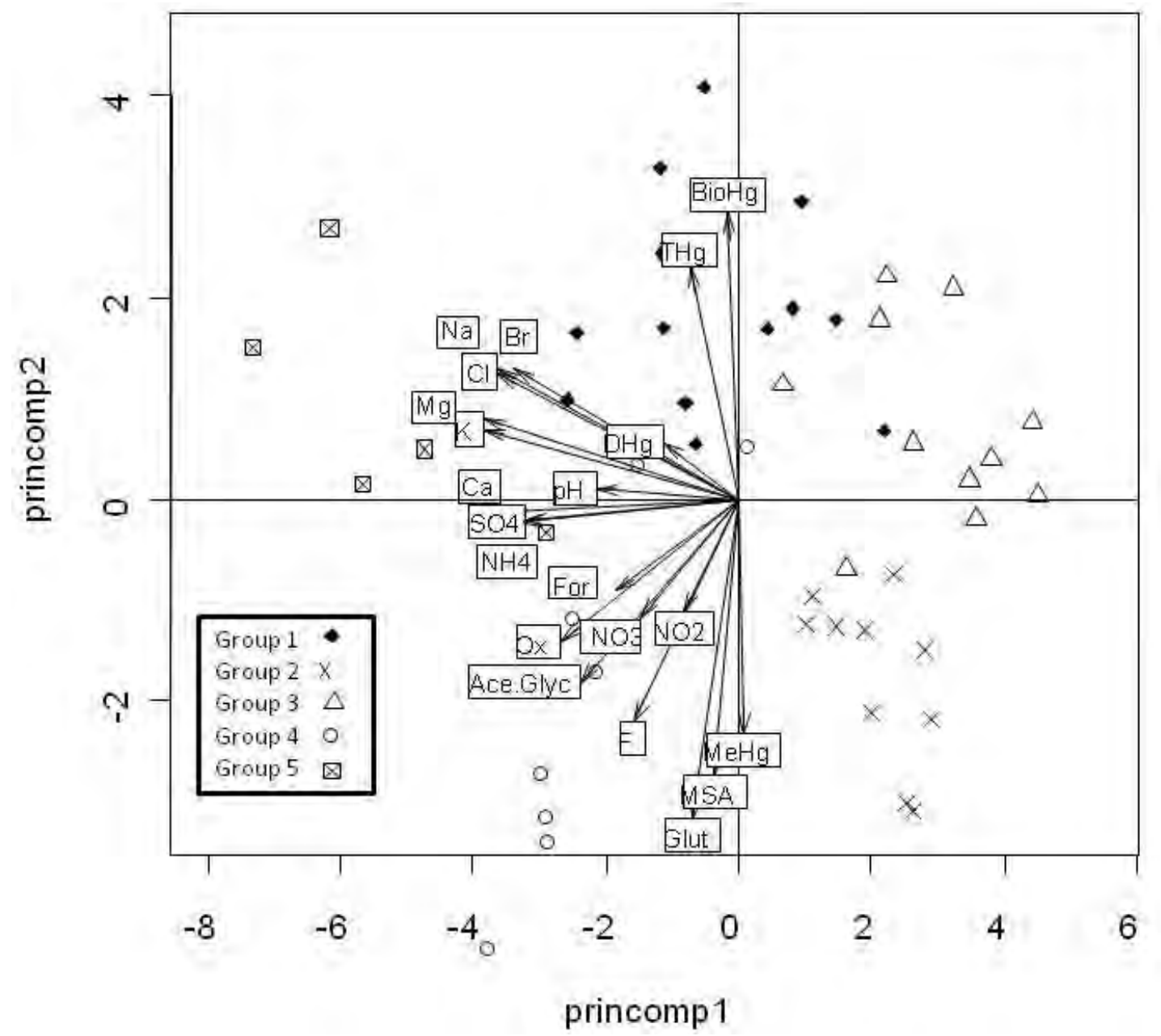

Figure 2: Principal component analysis for the sampling period. Chemical data ( $\mu \mathrm{mol} . \mathrm{L}^{-1}$ or $\mathrm{ng} . \mathrm{L}^{-1}$ for $542 \mathrm{Hg}$ species) were log-transformed prior to analysis. The data set covers the entire sampling period $\left(16^{\text {th }}\right.$ April- June $\left.8^{\text {th }}\right)$. Abbreviations: Glut=glutaric acid, MSA=methanesulfonic acid, Ox=oxalic acid, For=formate, F=fluoride, Ace.Glyc=acetate-glycolate, BioHg=bioavailable $\mathrm{Hg}$, $\mathrm{THg}=$ total $\mathrm{Hg}$, $\mathrm{MeHg}=$ methylmercury, $\mathrm{DHg}=$ dissolved total $\mathrm{Hg}$ 

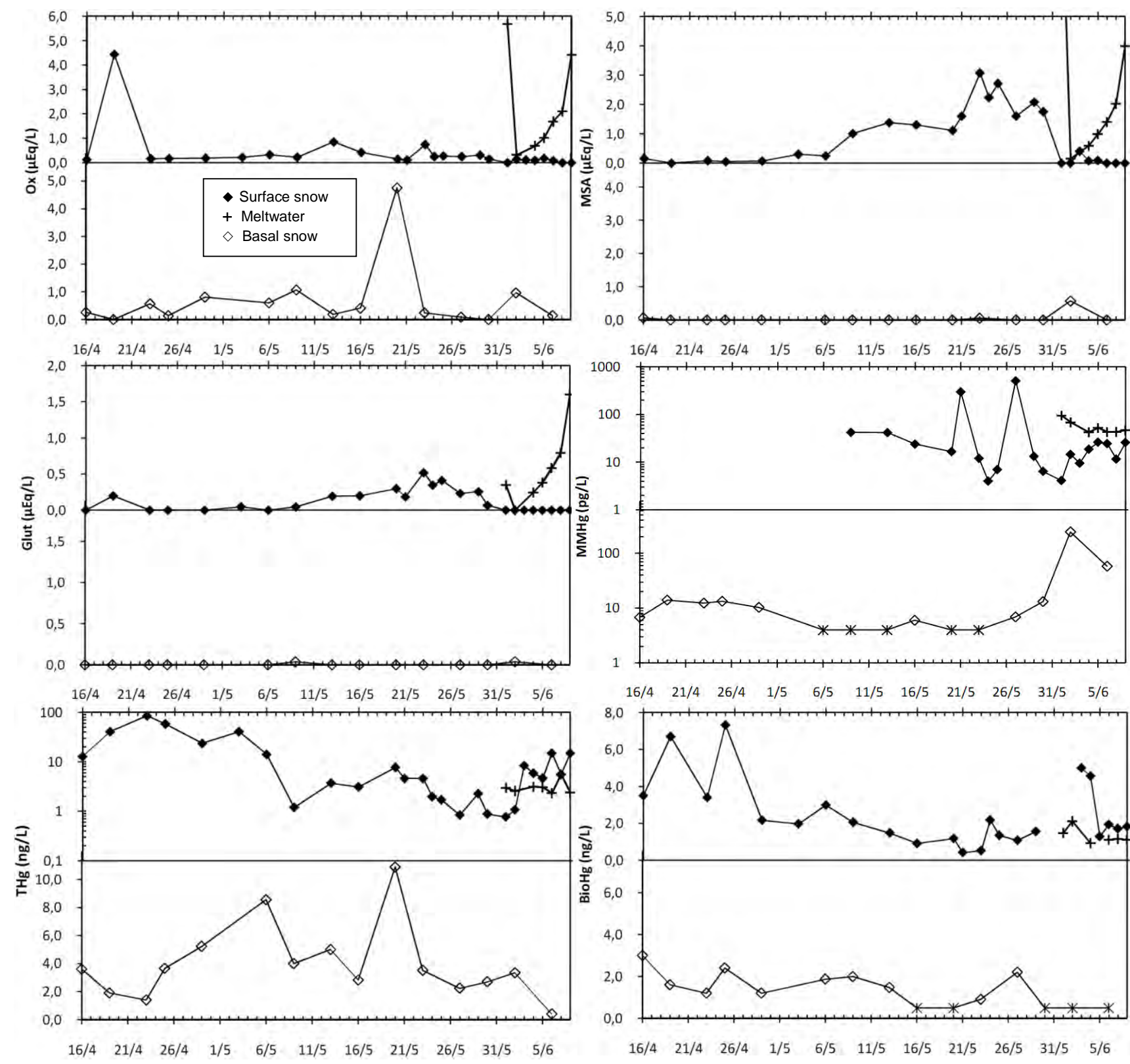

Figure 3: Chemical profiles over time for organics (MSA, glutaric acid, oxalic acid) and different mercury species. Organic concentrations are expressed in $\mu \mathrm{mol}^{-\mathrm{L}^{-1}}$, total mercury $(\mathrm{THg})$ and bioavailable mercury (BioHg) are expressed in $\mathrm{ng}^{-\mathrm{L}^{-1}}$. Monomethylmercury $(\mathrm{MMHg}$ ) concentrations are expressed in pg. $\mathrm{L}^{-1}$. Full squares represent surface samples, open squares represent basal samples and crosses are meltwater samples. Surface samples for $\mathrm{MMHg}$ and $\mathrm{HgT}$ are presented on a log-scale. All analyses were carried out in duplicate or triplicate and standard error was less than $10 \%$. 

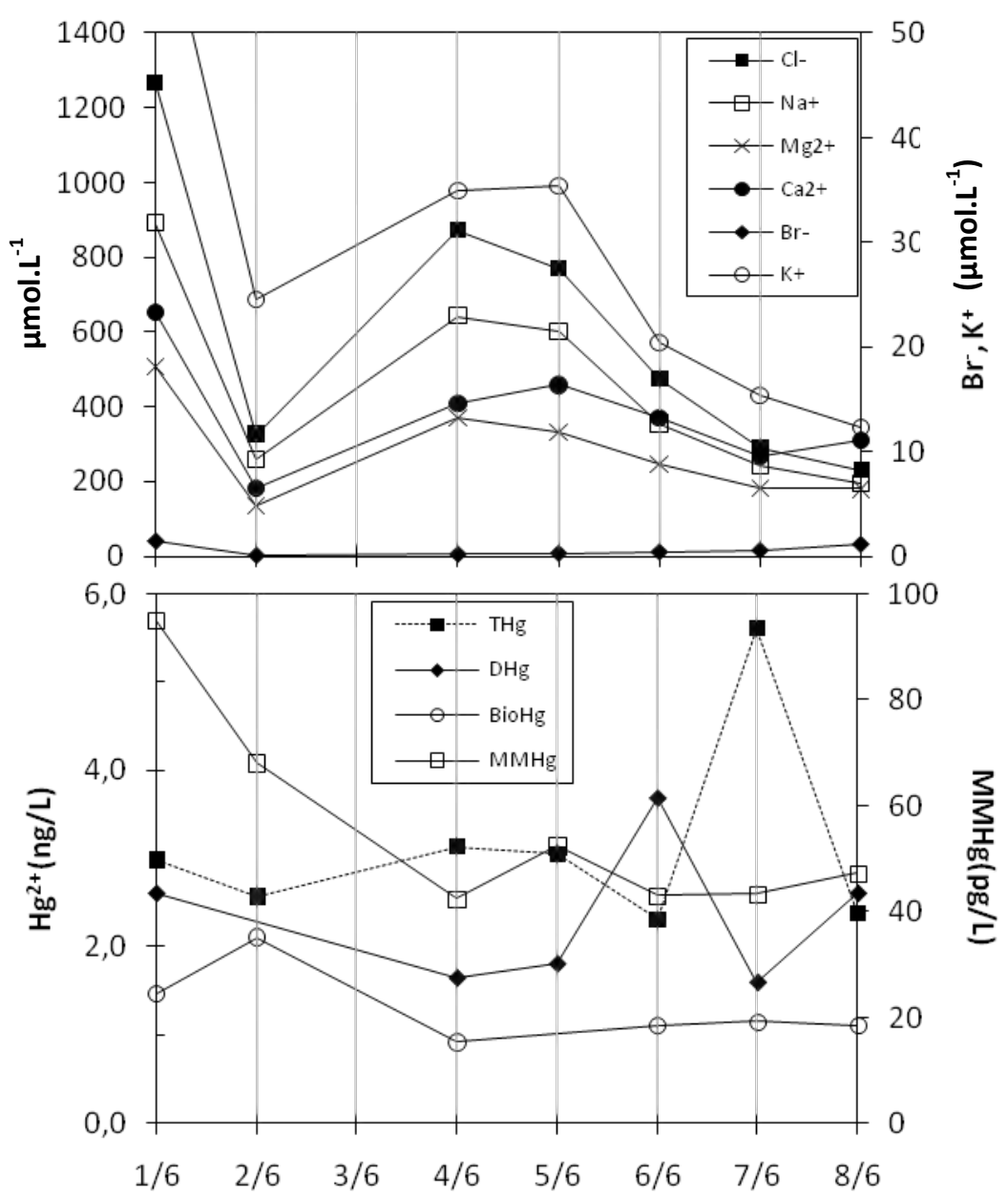

Figure 4: Meltwater elution curves for major ions and different mercury species over time. Ion concentrations are expressed in $\mu \mathrm{mol}^{-\mathrm{L}^{-1}}$, total $(\mathrm{THg})$, dissolved total $(\mathrm{DHg})$ and bioavailable $(\mathrm{BioHg})$ mercury concentrations are expressed in ng. $\mathrm{L}^{-1}$. Methylmercury $(\mathrm{MMHg})$ concentrations are in pg. $\mathrm{L}^{-1}$. Analyses were carried out in duplicate or triplicate and standard error was less than $10 \%$. 

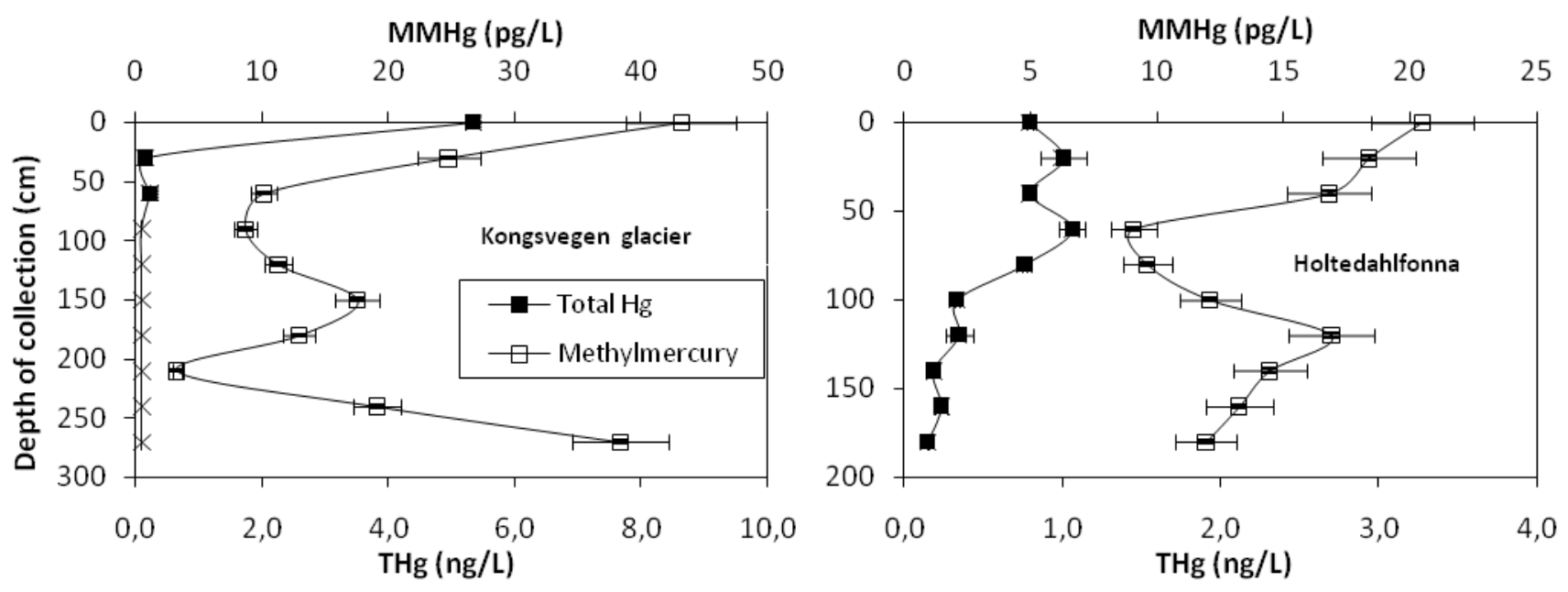

Figure 5: Snowpit total mercury ( $\mathrm{THg}$ ) and monomethylmercury (MMHg) profiles for Holtedahlfonna (sample date 30/04/2008) and Kongsvegen (sample date 19/05/2008) glaciers. 


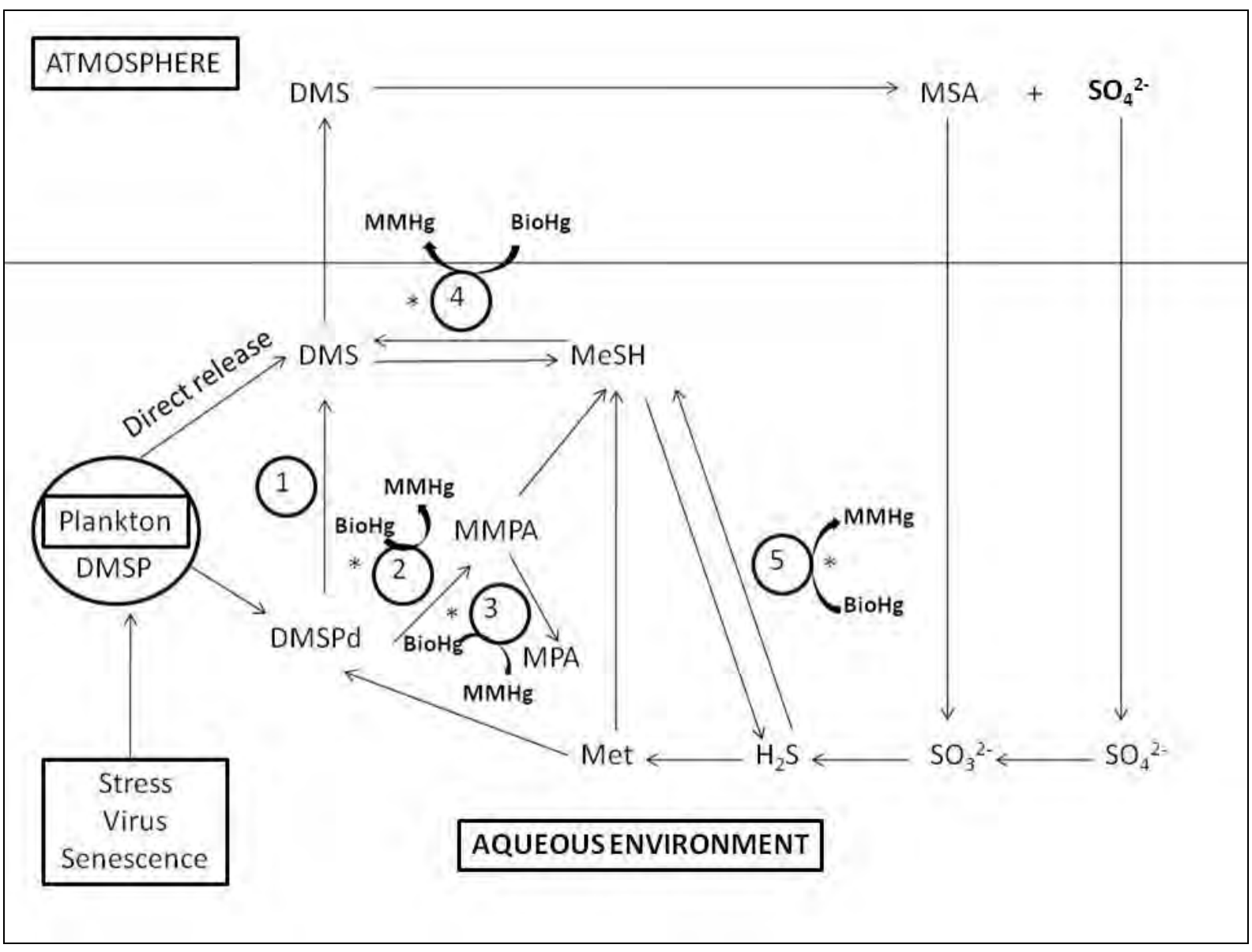

Figure 6: Sulfur cycle (modified from Bentley and Chasteen (2004)). The pathways represented here focus on biogenic transformations and the numbered pathways represent those discussed in the text. Other transformations occur, but are not addressed in this paper. The pathways are: 1 ) DMSPlyase. 2) Demethylation. 3) MMPA demethylation. 4) Thiol transmethylation. 5) Thiol transmethylation. The star symbol represents reactions where BioHg could potentially be methylated through methyltransfer reactions. 
AMAP, 2009. AMAP Assessment 2009: Human Health in the Arctic. Arctic Monitoring and Assessment Programme (AMAP), Oslo, Norway.

Amato P., Hennebelle R., Magand O., Sancelme M., Delort A. M., Barbante C., Boutron C., and Ferrari C. (2007) Bacterial characterization of the snow cover at Spitzberg, Svalbard. FEMS Microbiol. Ecol. 59, 255-264.

Ariya P. A., Khalizov A., and Gidas A. (2002) Reactions of gaseous mercury with atomic and molecular halogens: Kinetics, product studies, and atmospheric implications. J. Phys. Chem. A 106, 7310-7320.

Bales R. C., Davis R. E., and Williams M. W. (1993) Tracer release in melting snow: diurnal and seasonal patterns. Hydrolog. Process. 7, 389-401.

Barkay T., Gillman M., and Turner R. R. (1997) Effects of dissolved organic carbon and salinity on bioavailability of mercury. Appl. Environ. Microbiol. 63, 4267-71.

Barkay T. and Poulain A. J. (2007) Mercury (micro)biogeochemistry in polar environments. FEMS Microbiol. Ecol. 59, 232-41.

Bentley R. and Chasteen T. G. (2004) Environmental VOSCs--formation and degradation of dimethyl sulfide, methanethiol and related materials. Chemosphere 55, 291-317.

Berman M., Chase T., Jr., and Bartha R. (1990) Carbon Flow in Mercury Biomethylation by Desulfovibrio desulfuricans. Appl. Environ. Microbiol. 56, 298-300.

Brooks S., Lindberg S., Southworth G., and Arimoto R. (2008) Springtime atmospheric mercury speciation in the McMurdo, Antarctica coastal region. Atmos. Environ. 42, 2885-2893.

Campbell L. M., Norstrom R. J., Hobson K. A., Muir D. C. G., Backus S., and Fisk A. T. (2005) Mercury and other trace elements in a pelagic Arctic marine food web (Northwater Polynya, Baffin Bay). Sci. Total Environ. 351, 247-263.

Celo V., Lean D. R., and Scott S. L. (2006) Abiotic methylation of mercury in the aquatic environment. Sci. Total Environ. 368, 126-37.

Choi S. C., Chase Jr. T., and Bartha R. (1994) Enzymatic catalysis of mercury methylation by Desulfovibrio desulfuricans LS. . Appl. Environ. Microbiol. 60 1342-1346.

Christner B. C. (2002) Incorporation of DNA and protein precursors into macromolecules by bacteria at -15 degrees C. Appl. Environ. Microbiol. 68, 6435-8.

Colbeck S. C. (1981) A simulation of the enrichment of atmospheric pollutants in snow cover runoff. Water Resour. Res. 17 1383-1388.

Colbeck S. C. (1989) Air movement in snow due to windpumping. J Glaciol 35, 209-213.

Compeau G. C. and Bartha R. (1985) Sulfate reducing bacteria: principal methylators of mercury in anoxic estuarine sediment. Appl. Environ. Microbiol. 50, 498-502.

Constant P., Poissant L., Villemur R., Yumvihoze E., and Lean D. (2007) Fate of inorganic mercury and methyl mercury within the snow cover in the low arctic tundra on the shore of Hudson Bay (Québec, Canada). J. Geophys. Res. 112.

Cossa D., Averty B., and Pirrone N. (2009) The origin of methylmercury in open Mediterranean waters. Limnol. Oceanogr. 54, 837-844.

Daly G. L. and Wania F. (2004) Simulating the Influence of Snow on the Fate of Organic Compounds. Environ. Sci. Technol. 38, 4176-4186.

Davies T. D., Vincent C. E., and Brimblecombe P. (1982) Preferential elution of strong acids from a Norwegian ice cap. Nature 300, 161-163.

Dommergue A., Ferrari C. P., Poissant L., Gauchard P. A., and Boutron C. F. (2003) Diurnal cycles of gaseous mercury within the snowpack at Kuujjuarapik/Whapmagoostui, Quebec, Canada. Environ. Sci. Technol. 37, 3289-97. 
Dommergue A., Larose C., Faïn X., Clarisse O., Foucher D., Hintelmann H., Schneider D., and Ferrari C. P. (2010) Deposition of mercury species in the Ny-Ålesund area $\left(79^{\circ} \mathrm{N}\right)$ and their transfer during snowmelt. Environ. Sci. Technol. 44, 901-907

Douglas T. A. and Sturm M. (2004) Arctic haze, mercury and the chemical composition of snow across northwestern Alaska. Atmos. Environ. 38, 805-820.

Edwards A. C., Scalenghe R., and Freppaz M. (2007) Changes in the seasonal snow cover of alpine regions and its effect on soil processes: A review. Quatern. Int. 162-163 172-181.

Eichler A., Schwikowski M., and Gäggeler H. W. (2001) Meltwater induced relocation of chemical species in Alpine firn. Tellus 53B, 192-203.

Ferrari C. P., Moreau A. L., and Boutron C. F. (2000) Clean conditions for the determination of ultralow levels of mercury in ice and snow samples. Fresen. J. Anal. Chem. 366, 433-437.

Fitzgerald W. F., Lamborg C. H., and Hammerschmidt C. R. (2007) Marine Biogeochemical Cycling of Mercury. Chem. Rev. 107, 641-662.

Fleming E. J., Mack E. E., Green P. G., and Nelson D. C. (2006) Mercury Methylation from Unexpected Sources: Molybdate-Inhibited Freshwater Sediments and an Iron-Reducing Bacterium. Appl. Environ. Microbiol. 72, 457-464.

Gardfeldt K., Munthe J., Stromberg D., and Lindqvist O. (2003) A kinetic study on the abiotic methylation of divalent mercury in the aqueous phase. Sci. Total Environ. 304, 127-136.

Goto-Azuma K., Nakawo M., Han J., Watanabe O., and Azuma N. (1994) Melt-induced relocation of ions in glaciers and in a seasonal snowpack IAHS Publ. 223 287-298.

Grannas A. M., Bausch A. R., and Mahanna K. M. (2007a) Enhanced aqueous photochemical reaction rates after freezing. J. Phys. Chem. A 111, 11043-9.

Grannas A. M., Jones A. E., Dibb J., Ammann M., Anastasio C., Beine H. J., Bergin M., Bottenheim J., Boxe C. S., Carver G., Chen G., Crawford J. H., Dominé F., Frey M. M., Guzman M. I., Heard D. E., Helmig D., Hoffmann M. R., Honrath R. E., Huey L. G., Hutterli M., Jacobi H. W., Klan P., Lefer B., McConnell J., Plane J., Sander R., Savarino J., Shepson P. B., Simpson W. R., Sodeau J. R., von Glasow R., Weller R., Wolff E. W., and Zhu T. (2007b) An overview of snow photochemistry: evidence, mechanisms and impacts. Atmos. Chem. Phys. 7, 4329-4373.

Hall B., Bloom N. S., and Munthe J. (1995) An experimental study of two potential methylation agents of mercury in the atmosphere: $\mathrm{CH} 3 \mathrm{I}$ and DMS. Water Air Soil Pollut. 80, 337-341.

Hammerschmidt C. R., Lamborg C. H., and Fitzgerald W. F. (2007) Aqueous phase methylation as a potential source of methylmercury in wet deposition. Atmos. Environ. 41, 1663-1668.

Hinkler J., Hansen B. U., Tamstorf M. P., Sigsgaard C., and Petersen D. (2008) Snow and Snow-Cover in Central Northeast Greenland. Adv. Ecol. Res. 40, 175-195.

Hodgkins R., Tranter, M., and Dowdeswell, J. A. (1998) The hydrochemistry of runoff from a 'coldbased' glacier in the High Arctic (Scott Turnerbreen, Svalbard) Hydrol. Process. 12, 87103.

Johannessen M. and Henriksen A. (1978) Chemistry of snow melt water: changes in concentration during melting Water Resour. Res. 14, 615-619.

Johnson K. P., Blum J. D., Keeler G. J., and Douglas T. A. (2008) Investigation of the deposition and emission of mercury in arctic snow during an atmospheric mercury depletion event. $J$. Geophys. Res. 113, doi:10.1029/2008JD009893.

Jones H. G. (1999) The ecology of snow-covered systems: a brief overview of nutrient cycling and life in the cold. Hydrol Process 13, 2135-2147.

Kawamura K. and Ikushima K. (1993) Seasonal changes in the distribution of dicarboxylic acids in the urban atmosphere. Envir. Sci. Technol. 27, 2227-2235.

Kawamura K. and Kasukabe H. (1996) Sources and reaction pathways of dicarboxylic acids, ketoacids and dicarbonyls in Arctic aerosols: one year of observations. Atmos. Environ. 30, 1709-1722.

Kerin E. J., Gilmour C. C., Roden E., Suzuki M. T., Coates J. D., and Mason R. P. (2006) Mercury Methylation by Dissimilatory Iron-Reducing Bacteria. Appl. Environ. Microbiol. 72, 7919-7921. 
Kiene R. P., Linn L. J., and Bruton J. A. (2000) New and important roles for DMSP in marine microbial communities. J. Sea Res. 43, 209-224.

Kirk J. L., St. Louis V. L., Hintelmann H., Lehnherr I., Else B., and Poissant L. (2008) Methylated Mercury Species in Marine Waters of the Canadian High and Sub Arctic. Environ. Sci. Technol. 42, 8367-8373.

Kirk J. L., St. Louis V. L., and Sharp M. J. (2006) Rapid Reduction and Reemission of Mercury Deposited into Snowpacks during Atmospheric Mercury Depletion Events at Churchill, Manitoba, Canada. Environ. Sci. Technol. 40, 7590-7596.

Kuhn M. (1987) Micro-meteorological conditions for snow melt J Glaciol 33, 24-26.

Kuhn M. (2001) The nutrient cycle through snow and ice, a review. Aqua. Sci. 63, 150-167.

Lalonde J. D., Poulain A. J., and Amyot M. (2002) The role of mercury redox reactions in snow on snow-to-air mercury transfer. Environ. Sci. Technol. 36, 174-178.

tarose C., Dommergue A., Ferrari C., Marusczak N., Coves J., and Schneider D. (2010) Detection of bioavailable $\mathrm{Hg}$ deposited in Polar regions. The ISME Journal submitted.

Leck C. and Persson C. (1996) The central Arctic Ocean as a source of dimethyl sulfide - Seasonal variability in relation to biological activity Tellus 48B, 156-177.

Legrand M., Preunkert S., Oliveira T., Pio C. A., Hammer S., Gelencsér A., Kasper-Giebl A., and Laj P. (2007) Origin of C2-C5 dicarboxylic acids in the European atmosphere inferred from yearround aerosol study conducted at a west-east transect. J. Geophys. Res. 112, D23S07, doi:10.1029/2006JD008019.

Lei Y. D., D. Y., and Wania F. (2004) Is rain or snow a more efficient scavenger of organic chemicals? Atmos. Environ. 38, 3557-3571.

Lindberg S. E., Brooks S., Lin C. J., Scott K., Meyers T., Chambers L., Landis M., and Stevens R. (2001) Formation of Reactive Gaseous Mercury in the Arctic: Evidence of Oxidation of $\mathrm{Hg}^{\circ}$ to GasPhase Hg-II Compounds after Arctic Sunrise. Water Air Soil Poll. Focus 1, 295-302.

Lindberg S. E., Brooks S., Lin C. J., Scott K. J., Landis M. S., Stevens R. K., Goodsite M., and Richter A. (2002) Dynamic Oxidation of Gaseous Mercury in the Arctic Troposphere at Polar Sunrise. Environ. Sci. Technol. 36, 1245-256.

Loseto L. L., Lean D. R. S., and Siciliano S. D. (2004) Snowmelt Sources of Methylmercury to High Arctic Ecosystems. Environ. Sci. Technol. 38, 3004-3010.

Lu J. Y., Schroeder W. H., Barrie L. A., Steffen A., Welch H. E., Martin K., Lockhart L., Hunt R. V., Boila G., and Richter A. (2001) Magnification of atmospheric mercury deposition to polar regions in springtime: the link to tropospheric ozone depletion chemistry. Geophys. Res. Lett. 28, 32193222.

Lyons W. B., Welch K. A., Fountain A. G., Dana G. L., Vaughn B. H., and McKnight D. M. (2003) Surface glaciochemistry of Taylor Valley, southern Victoria Land, Antarctica, and its relation to stream chemistry. Hydrolog. Process. 17 115-130.

Meyer T., Lei Y. D., and Wania F. (2006) Measuring the release of organic contaminants from melting snow under controlled conditions. Environ. Sci. Technol. 40, 3320-3326.

Meyer T. and Wania F. (2008) Organic contaminant amplification during snowmelt. Water Res. 42 , 1847-1865.

Monperrus M., Tessier E., Amouroux D., Leynaert A., Huonnic P., and Donard O. F. X. (2007) Mercury methylation, demethylation and reduction rates in coastal and marine surface waters of the Mediterranean Sea. Mar. Chem. 107, 49-63.

Narcy F., Gasparini S., Falk-Petersen S., and Mayzaud P. (2009) Seasonal and individual variability of lipid reserves in Oithona similis (Cyclopoida) in an Arctic fjord. Polar Biol. 32, 233-242.

Niki H., Maker P. D., Savage C. M., and Breitenbach L. P. (1983a) A long-path Fourier transform infrared study of the kinetics and mechanism for the hydroxyl radical-initiated oxidation of dimethylmercury. J. Phys. Chem. 87, 4978-4981. 
Niki H., Maker P. S., Savage C. M., and Breitenbach L. P. (1983b) A Fourier-transform infrared study of the kinetics and mechanism of the reaction of atomic chlorine with dimethylmercury. J. Phys. Chem. 87, 3722-3724.

Poulain A. J., Lalonde J. D., Amyot M., Shead J. A., Raofie F., and Ariya P. A. (2004) Redox transformations of mercury in an Arctic snowpack at springtime. Atmos. Environ. 38, 67636774.

Poulain A. J., Ni Chadhain S. M., Ariya P. A., Amyot M., Garcia E., Campbell P. G. C., Zylstra G. J., and Barkay T. (2007) Potential for mercury reduction by microbes in the high arctic. Appl. Environ. Microbiol. 73, 2230-2238.

Reisch C. R., Moran M. A., and Whitman W. B. (2008) Dimethylsulfoniopropionate-dependent demethylase (DmdA) from Pelagibacter ubique and Silicibacter pomeroyi. J. Bacteriol. 190, 8018-24.

Rontani J.-F. (2001) Visible light-dependent degradation of lipidic phytoplanktonic components during senescence: a review. Phytochemistry 58, 187-202.

Schroeder W. H., Anlauf K. G., Barrie L. A., Lu J. Y., Steffen A., Schneeberger D. R., and Berg T. (1998) Arctic springtime depletion of mercury. Nature 394, 331-332.

Scott K. J. (2001) Bioavailable mercury in arctic snow determined by a light-emitting mer-lux bioreporter. Arctic 54, 92-95.

Siciliano S. D., O'Driscoll N. J., Tordon R., Hill J., Beauchamp S., and Lean D. R. S. (2005) Abiotic production of methylmercury by solar radiation. Environ. Sci. Technol. 39, 1071-1077.

St. Louis V. L., Hintelmann H., Graydon J. A., Kirk J. L., Barker J., Dimock B., Sharp M. J., and Lehnherr I. (2007) Methylated mercury species in Canadian high arctic marine surface waters and snowpacks. Environ. Sci. Technol. 41, 6433-6441.

St. Louis V. L., Sharp M. J., Steffen A., May A., Barker J., Kirk J. L., Kelly D. J. A., Arnott S. E., Keatley B., and Smol J. P. (2005) Some sources and sinks of monomethyl and inorganic mercury on Ellesmere island in the Canadian high arctic. Environ. Sci. Technol. 39, 2686-2701.

Stoichev T., Rodriguez Martin-Doimeadios R. C., Tessier E., Amouroux D., and Donard O. F. (2004) Improvement of analytical performances for mercury speciation by on-line derivatization, cryofocussing and atomic fluorescence spectrometry. Talanta 62, 433-8.

Sunderland E. M., Krabbenhoft D. P., Moreau J. W., Strode S. A., and Landing W. M. (2009) Mercury sources, distribution, and bioavailability in the North Pacific Ocean: Insights from data and models. Global Biogeochem. Cycles 23.

Tranter M., Brimblecombe P., Davies T. D., Vincent C. E., Abrahams P. W., and Blackwood I. (1986) A composition of snowfall, snowpack and meltwater in the Scottish Highlands-evidence for preferential elution Atmos. Environ. 20, 517-525.

Tseng C. M., Garraud H., Amouroux D., Donard O. F., and de Diego A. (1998) Open focused microwave-assisted sample preparation for rapid total and mercury species determination in environmental solid samples. J. Autom. Chem. 20, 99-108.

Wagemann R., Trebacz E., Boila G., and Lockhart W. L. (1998) Methylmercury and total mercury in tissues of arctic marine mammals. Sci. Total Environ. 218, 19-31.

Weber J. H. (1993) Review of possible paths for abiotic methylation of mercury(II) in the aquatic environment. Chemosphere 26, 2063-2077.

Williams M. W., Seibold C., and Chowanski K. (2009) Storage and release of solutes from a subalpine seasonal snowpack: soil and stream water response, Niwot Ridge, Colorado. Biogeochemistry 95, 77-94. 